\title{
National Integration and Peaceful Co-Existence in Nigeria: The Role of Inter-Ethnic/Inter-Religious Marriages
}

\author{
Christian Emeka Chukwu \\ https://dx.doi.org/10.4314/jrhr.v13i1.11
}

\section{Abstract}

It is no longer news that Nigeria as one united political and geographical entity has continued to experience inter-religious and inter-ethnic sentiments bickering, misunderstanding, mistrust which have constantly snowballed into crisis of tremendous proportion. As a result, many innocent lives and properties worth billions of naira have been lost. This ugly situation has continued to threaten the corporate existence of Nigeria and retrogressively affected the socioeconomic development of Nigeria. However, when there is no genuine effort to bring about genuine national integration, peaceful coexistence will definitely be a mirage. One of the factors or strategies identified as capable of fostering national integration and guaranteeing peaceful co-existence is inter-ethnic, inter-religious and even inter-communal marriages among the people of different ethnic groups and adherents of different religions in Nigeria. This paper clarifies concepts in the write-up and also points out how intermarriages can foster peace and unity. It also recommends that traditional and religious leaders should be encouraged to inspire those they watch over to embrace this type of mixed marriage in order to achieve sustainable national development and most importantly promote peaceful coexistence among different ethnic groups in Nigeria

Keywords: National Integration, Peaceful Co-existence, Marriage, Inter-ethnic and Inter-Religious Marriage 


\section{Introduction}

Since the southern and northern protectorates were amalgamated in 1914 by the then British colonial government and gained political independence from Britain on October $1^{\text {st }} 1960$, Nigeria as a political entity or socio-political structure has been under threats of disintegration, a threat which exists as a result of lack of understanding and harmony among the different ethnic nationalities that make up Nigeria as an independent and a sovereign state. These lack of understanding, unity, peace and harmony among these ethnic nationalities that constitute the Nigerian state, may be attributed to differences or diversities evident in the culture, language, religion and most importantly the worldview of the various ethnic nationalities that make up the political structure called Nigeria.

As a result of this lack of understanding among the citizens of Nigeria, the quest or the effort of all well-meaning patriotic citizens and leaders to promote national integration and peaceful coexistence had been an uphill task. Consequently, conflicts, crises, misunderstanding, terrorism, banditry, nepotism, marginalization, separatist agitations and most recently the deafening call for selfdetermination by some ethnic groups and so on, which have political, tribal and religious coloration or undertone, are seriously threatening the existence of this great nation called Nigeria. Fear of domination of one tribe or ethnic group by others and frequent hues and cries of one tribe marginalizing the other and accusation of having a hidden agenda or ulterior motive and so on, had given birth to the dangerous level of tribal or ethnic consciousness among citizens, instead of a strong feeling of national consciousness and patriotism.

However, these ethnic nationalities, rather than see one another as brothers and sisters with one vision and one destiny as citizens of Nigeria, have continued to see one another as arch enemies that must be crushed, annihilated, eliminated, perpetually silenced, and subjugated by whatever means. Hostilities and hatred of one ethnic 
group or religious adherents against the other have snowballed into anarchy, chaos, religio-political conflicts, ethnic or racial profiling and more recently ethno-religiously motivated acts of terrorism and banditry perpetrated by non-state actors.

Unfortunately, the cost of the above vices on the peace, unity and the development of the nation cannot be over-emphasized. Innocent lives and property worth of billions naira if not dollars are being destroyed almost on daily basis. The country's international rating in almost all the areas or indices of human and physical development is at its lowest ebb. The potentials of Nigeria as an emerging super power based on her abundant human and material resources are now a mirage. In fact, the country is now battling to survive, avoid disintegration and attaining failed state status. The much publicized vision 20:2020 that is the vision of Nigeria becoming one of the twenty largest economies by the year 2020 could not be unachievable, as a result of lack of national integration and peaceful co-existence. The inability of the nation to achieve national integration which facilitates peaceful co-existence is a cog in the wheel of progress and development, as no nation achieves economic and political growth and development in an atmosphere of crisis, conflicts, strives, rancor and unhealthy tribal cum religious sentiments, mutual suspicion, hatred and rivalry. Though the prediction of a United States agency or organization that Nigeria as a country may cease to exist by $2015 \mathrm{did}$ not come to fulfillment, but now Nigeria as a nation is deeply polarized along religious and ethnic lines.

\section{Conceptualizing National Integration and Peaceful Co-Existence}

It is of paramount importance for a country as diverse as Nigeria to pursue with vigor the full attainment of national integration, so as to promote peaceful co-existence among different ethnic groups that make up the geopolitical territory called Nigeria. It is a universal truth that national integration and peaceful co-existence go hand in hand, 
just like Siamese twinswhich cannot be separated easily. This relationship could further be explained or construed in the sense that none can exist without the other. In other words, no nation can enjoy peaceful co-existence without laying a solid foundation that would precipitate, encourage or entrench national integration.

However, it is universally acknowledged that no country or nation can achieve sustainable development or economic growth in an atmosphere of inter-tribal and inter-religious hostilities, hence the need to promote national integration and peaceful co-existence so as to ensure social-economic and political growth and sustainable development. Therefore, if national integration guarantees peaceful coexistence, what then do we mean by national integration and peaceful coexistence?

Hornby,(2006), defines a nation as a group of people with the same language, culture, history, who live in a particular area under one government. The same source also defines integration as the act or the process of combining two or more things so that they work together.

Global Policy Forum (n.d) defines a nation as a large group of people with strong bonds of identity - an "imagined community," a tribe on a grand scale". Onyeakazi and Okorafor (2018) view national integration as "the process of bringing the various peoples of different cultural and social background together in a given social context or polity for their collective interests and good". Weiner (1967) sees national integration as a conscious effort geared towards the creation of a territorial nationality that overshadows or eliminates every form parochial loyalties. In other words, national integration is the aggregate of all efforts geared towards the creation of the feeling of oneness among people living in a particular geographical location, irrespective of the differences that may exist among them.

Furthermore, national integration is the awareness of a common identity amongst the citizens of a country (Khurana, n.d) National 
integration connotes a process or the act of forging a common identity by all the citizens of a country, so as to ensure unity, peaceful coexistence and sustainable development. National integration can also be construed in the sense that in a heterogeneous society such as Nigeria, where there are distinct differences in our cultures, languages and religions, there is need for us to appreciate and recognize the inherent truth that we are one indivisible, indissoluble, united country having a common destiny and aspiration toward the overall development of the nation and the wellbeing of all citizens irrespective of tribe, language or religion. National integration entails the process or the act of igniting the fire or the awakening of the spirit of patriotism and nationalism in the hearts, minds and souls of the citizens of a given country. It also means putting the welfare of the country first before any other primordial or parochial tribal or religious sentiments.

It is worthy of note, that the idea of national integration does not connote the outright denial of ethnic, tribal, cultural or religious differences, which are in most cases glaring, overt or crystal clear, but it presupposes the act of acknowledging these differences and ignoring them,that is not allowing these factors to be object of disunity or division. Through this strategy, the Nigeria citizens respective of their tribe, religion or culture and so on, can build a common identity that promotes unity and peaceful co-existence which will automatically give rise to socioeconomic development.

Interestingly, the idea of national integration in a heterogeneous society like Nigeria simply presupposes the quest for unity in diversity. In other words, unity in diversity entails unity in the midst of observable or overt differences. However, it is a conscious effort aimed at ignoring or neglecting all the factors that promote division, prejudices, discrimination, injustice, extreme and negative ethnocentrism, and marginalization and so on, among the citizens of a nation such as Nigeria. 
Nikky, (2010) sees national integration as national unity. She explained this to mean unity in diversity that is the idea of unifying or uniting all forces in a country thereby building the idea of one nation. This means nation devoid of tribal or religious prejudice, bias, hatred and so on. In other words, there is great need to create this consciousness in the hearts and minds of every citizen of Nigeria.

It is worthy of note, that one cannot understand fully the concept of peaceful co-existence, without being familiarized with the word "Peace". From the foregoing, it is important to note that peace emanates from a person's state of mind, this means that a person who does not have peace within himself or herself cannot establish peace with another person. Therefore, it also follows that an individual or group of people that do not cherish or enjoy internal peace among them cannot establish peace with another individual or group.

Peace is not just the absence of war, but the prevention of all structural and social inequalities (Algera 1989). Here the importance of justice, equity, fairness and so on, as a panacea to peace and peaceful coexistence in our society was brought to the fore. It is worthy of mention, that where there is no justice, there will be no peace. Therefore, Justice and Peace are two birds of the same feathers that should flock together or two sides of a single coin. Peace according to Abdulrasheed (2013) means beneficent adjustment of harmony between the individual and his creator on one hand, and his fellow men on the other hand.

The importance of peace to societal harmony cannot be ignored, this is evident in the words of Francis (2006), when he opined that peace is the prime value in all human societies, he also described peace as the most valuable public good, and yet the most elusive in our human society. The idea of peace to Francis (2006) means absence of war, fear, conflict, anxiety, suffering and violence. Precisely, peace is justice, development, respect, tolerance and love among people (Asuquo, 2013). Therefore, peace is an important 
factor for human survival and sustainable development. Peace to a great extent is synonymous to life and good health. It guarantees and facilitates human life, good health and societal life and health. When the society is peaceful, it promotes the life, health and total well-being of the people which translates to development both human and infrastructural development.

Therefore, peaceful co-existence on the other means a situation whereby all the members of a given society live in harmony, love, mutual respect, tolerance and so on, irrespective of their differences in terms of religion, tribe, languages or social status. Peaceful coexistence is a sine qua non to economic development of any nation, as no nation develops in an atmosphere of chaos, conflicts, anarchy, intolerance mistrust etc. Candidly for any heterogeneous society to ensure or achieve peaceful co-existence, love, mutual respect, tolerance, justice, fairness, equity and so on, must be promoted and imbibed by all and sundry, so as to build an enabling environment that would propel the realization of a country's vision and accelerate her speedy sustainable socio-economic development.

\section{The Concept of Marriage}

Marriage is regarded as one of the earliest institutions, if not the first institution founded by the Almighty God Himself when He said 'it is not good for the man to live alone, I will make a suitable companion to help him "(GNB Gen 2:18). Therefore, with these words, God created the institution of marriage. The United States Conference of Catholic Bishops (n.d) in accepting the divine origin of marriage, in describing marriage as the intimate union and equal partnership of a man and a woman, explained that marriage basically entails:

A committed, permanent, faithful relationship of husband and wife is the root of a family, strengthens all the members, provides best for the needs of children, and causes the church of the home to be an effective sign of Christ in the world. (n.p). 
From the foregoing, the sacrosanct vis-à-vis the indissoluble nature of marriage as a divinely ordained union between a husband and a wife according to the doctrine of the Catholic Church, cannot be over exaggerated. Chiegboka (2012) brought to the fore, the importance of marriage in our human society, Christian religion and the Catholic Church in particular. He went further to define the institution of marriage as:

The basic, natural, sacred and central human institution, it is the nucleus or vital cell of the human societies in so far as it inaugurates human family. This marriage bond, the most sacred of all human bonds, creates the family which is the domestic church, a place where human society begins, the basic unit or truly vital cell of civilized society, and an institution fundamental to society. (p.5).

However, the idea of marriage among the indigenous African people is all embracing; it is not only the affair of the bride and the groom, but the affairs of their families, the extend family, even communities. Agreeing with the truth that marriage acts as a bond which unites people, Odukoya, (2003) sees the concept of marriage as a phenomenon which involves the fusion of individuals and families.

By joining a man and a woman together, marriage brings about a mortal unity between a husband and his wife or wives. Most importantly, it is embedded with the ability or power that is capable of uniting people of different backgrounds irrespective of their overt and covert differences, such as tribe, conjugate religion, socialeconomic status etc.

Furthermore, marriage is a union or the coming together of a man and a woman to become husband and wife. One of the significance of marriage is that it brings people together, thereby bringing about harmony, peace, emotional and sexual satisfaction. It is one of the socio-cultural institutions that encourages and sustains public 
morality, for it controls man's sexual activities and wears man the garb of responsibility. Hence, in African culture, a married man is considered more responsible than a man who has reached the age of marriage but yet shows no interest in getting married.

\section{Conceptualizing Inter-Tribal and Inter-Religious Marriage}

Intertribal or inter-ethnic marriage is a form of marriage where a man and a woman from different tribes or ethnic group come together in a marriage institution. It presupposes a situation whereby a man or a woman marries outside his or her tribe or ethnicity. In other words, inter-tribal marriage is a marriage between a man and a woman of different ethnic groups or tribes. Inter-religious marriage presupposes a situation whereby a man and a woman from different religious beliefs come together as husband and wife.

Interestingly, these forms of marriage are now very common among our youths, who do not see anything morally wrong in marrying someone from a different tribe, religious or denominational background. To the majority of these youths, the most important factor to consider is the strength of the love they have for each other, and also their level of compatibility that is their ability to understand and tolerate their differences. Most times, parents even among the educated ones see it as their right to choose whoever their sons or daughters marry. The reason for this parental interference in their children choice of marriage partners is based on their thinking or perception that their children being in experienced in matters of life, do not know exactly what they want and factors to consider in making such important decision, as a result them being blind folded by the folly called love, which can overtime become an illusion. It is worthy of note that the above situation is commonly observed in African societies where marriage are arranged by parents for their children. Therefore, nowadays, the youths who are now more educated, sophisticated and are greatly or maximally utilizing the various social 
media platforms such as Facebook, Twitter, Instagram, Whatsapp and so on, to interact with people of other tribes and do not hesitate to go against their families' opinion in marrying a person of their choice irrespective of the their tribal and religious affiliations.

Furthermore, most parents who are tribal sensitive especially as it concerns marriage always wish and wield a strong influence on their children to marry within their tribe. The reason for this is not farfetched; some of these parents have erroneous beliefs regarding the cultures of other tribes. Among these erroneous belief are that the women from other tribes are promiscuous, proud, lazy etc. Also men from other tribes are considered as having the likelihood to maltreat their wives, especially if she is from another tribe. Another major reason is the obnoxious or harmful widowhood practices that were practiced in some tribes many years ago, a situation whereby a widow is being treated inhumanly and properties belonging to her husband taken away by her husband's relatives. However, these erroneous beliefs are mainly based on parochial cum primordial sentiments or erroneous stereotypes or fallacious generalizations, which can never be proved or substantiated by any means whatever.

Moreover, even when all the barrier against inter-tribal marriage are being dismantled on daily basis, as a result of the fact that many tribes now have opportunities to interact especially among the youths, the same cannot be said of inter-religious marriage. In Nigeria, it is unheard of that a Muslim from the northern part. of the country would allow his daughter marry a Christian who hails from the same northern. Interestingly, that same Muslim will be very enthusiastic if his son marries a Christian. In the same vein, a Christian parent who tend to be fanatical as regards his denomination will never allow his child marry outside their denomination not to talk of marrying a nonChristian.

However, the above situation is different among the Yoruba and few other tribes, where it is a common sight to see a family where 
members practice or profess different religions such as Christianity, Islam, and African Traditional Religion. It is not a surprise to see a Muslim husband and a Christian wife or vice-versa enjoying their marriage and family without considering their religious differences. This interesting situation has been adjudged as the main reason while inter-religious conflicts are not in existence in major cities in south western part of Nigeria such as Lagos, Ibadan and so.

Therefore, the friendly attitude of the Yoruba's toward religious plurality or diversity and how they have not allowed religion and tribal considerations to fan the embers of disunity, enmity, discrimination, hatred and so on, among themselves and ,with members of other tribes and religions, is highly commendable and should be emulated by other tribes in Nigeria. Interestingly, religion should be viewed as an agent of peace and unity and should not be used as instrument of hate.

In other words, the above line of thought is based on the conviction that no religion is superior to another or has a complete revelation of God, man, the universe and the relationship that exists amongst these factors. The view expressed above was reechoed by Madu (2003), when he averred that religion qua religion is one, he further explained that all religions are partners in progress. Therefore, role of inter-tribal and inter religious marriage in promoting national integration and peaceful co-existence cannot be denied.

It is an undisputable truth that Nigeria is a highly heterogeneous society, where many tribes speaking different languages, a country that has a great number of its citizens practice or profess the two greatest religions of the world. Christianity and Islam, needs to invest much effort so as to create feasible strategies that would ensure the much elusive national integration and entrench the culture of peaceful co-existence. This can be achieved by encouraging youths of different ethnic groups, or religions to inter-marry. 
It has been observed that one of the reasons for the enactment of the law establishing the National Youth Service Corp (NYSC) is to promote national integration and peaceful co-existence by, giving our youths the opportunity to interact with the people of other tribes, their environment and culture. Such interactions and appreciation of other people's culture have given rise to high rate of intertribal and interreligious marriage This have further strengthened the chord of unity among various ethnic nationalities since the end of the unfortunate Nigerian civil war.

In defense of inter-tribal marriage as a potent chord that ensures unity, peace, and harmonious co-existence, Adegbulugbe (2007), pointed out that inter-tribal marriage succeeds and even more successful than tribal marriage, as a result the youths should not be afraid to enter into it so as to promote the unity of the country. The role of intertribal marriage as a promoter of national integration and peaceful co-existence was further stressed by Azuh (nd) when he identified tribalism and ethno centralism as one of the factors militating against progress and development of Nigeria. Therefore, to ameliorate this situation intertribal cum inter-religious marriage should be encouraged among our youths, so as to strengthen our nascent democracy and bring about the needed development.

From the forgoing, it is crystal clear that democracy, good governance and sustainable development cannot take root in our country, if we do not encourage intertribal and interreligious marriage. Meliga (2013) was right in acknowledging the fact that most people agree that intertribal marriages foster unity among the people of Nigeria and can be veritable tool for national integration. The reason for the above assertion is not far-fetched; those who married from other tribes are found to be more open, liberal, accommodating and often radiate with tolerance in their interaction and association with the people of other tribes. 
Therefore, Nigeria being a multi-tribal, multi-lingual and a multireligious nation is vulnerable to inter-ethnic land interreligious misunderstanding. Hence, there is great need to inculcate in the psyche of every Nigerian, the positive attitude that would promote and facilitate inter-tribal cum intercultural harmony, tolerance, peaceful co-existence and sustainable socio economic development. To achieve, this inter-tribal cum inter-religious marriage should be encouraged by all and sundry.

\section{Recommendations}

1. It is obvious that the ship of the Nigerian state is drifting towards anarchy and failed state status, as a result of lack of genuine effort to bring about national integration. To arrest the above ugly situation, inter-tribal and inter-religious marriage must be encouraged among different tribes and religions.

2. The government as an institution, through its agencies such as the National Orientations, Agency (NOA), Ministries of Cultural and Tourism and so on, should as a matter of urgency come up with programmes that would enlightened the Nigerian citizens from different tribes and religions on the need to embrace intertribal cum inter-religious marriage.

3. Traditional rulers and religious leaders must be made to understand the fact that peace and development are prerequisite for both their cherished culture and religion to thrive. Hence, the onus is on them to encourage intertribal and interreligious marriage among their people, followers and people of other tribes and religions.

4. Being ethnocentric and passionate about one's culture and religion is not bad, but looking down on other people as a result of their culture and religion is condemnable in its entirety. In fact, people should appreciate other people, irrespective of their tribe or religion, as this can be practically expressed by contracting marriage with the people of other tribes and religions. In doing this 
we would be enriching our culture and entrenching the universal principle of the fatherhood of God and brotherhood of all mankind.

5. Parents and relatives must be properly enlightened to base their approval and disapproval of their children's marriage partners on the person's personality and the content of their character, not on the primordial sentiments of tribe, language, and religion.

6. Lastly, there should be a change of attitude by all and sundry. In fact, tribalism and all forms of religious fanaticism extremism or bigotry must be jettisoned by all well-meaning Nigerian. Therefore, we should appreciate the eternal truth that no culture or religion is supreme, in fact religion and culture are dynamic as a result of social interaction. However, rather than being afraid, we should be consoled with the fact that inter cultural interaction enriches our culture and solidifies our identity. This argument is based on the fact or the premise that when different cultures meet and interact new and better ways of doing things are learnt.

7. Finally, religious leaders should preach the message of unity, love, peace and not sermons of hatred, animosity, prejudices, division etc.

\section{Conclusion}

Nigeria's unity, development and peaceful co-existence are not negotiable. Our diversities in area of culture language, tribe, and religion, must be seen by all as a blessing and not a curse, because variety they say is the spice of life. Concerted effort must be put in place by formulation of policies and reforms that would help promote national integration and peaceful co-existence. However, one of the strategies that must be pursued to ensure a far-reaching national integration and peaceful co-existence is to create a meeting point that would ensure and enhance integration between one ethnic nationality or tribe and another. One of the ways by which this noble idea can be achieved is by putting up a strong advocacy and support for intertribal 
and interreligious marriage. Candidly, this type of marriage is capable of bridging the gap and filling the vacuum created by lack of genuine interaction and understanding between one ethnic nationality or religion and the other. Intertribal and interreligious marriage, if encouraged in a multi-ethnic cum multi-religious society like Nigeria would eradicate all manner of prejudices, bias, and stereotype s which one tribe or religion have against the other.

As the chord binding Nigeria as one united nation became stronger after the 2015 and 2019 election, an election in which factors such as religion and tribalism were used to divide us. There is need for us to pursue with vigor strategies that would strengthen and lengthen this eternal chord that binds us. This can be achieved through a strong advocacy for intertribal and interreligious marriage. When this is done, full national integration and peaceful co-existence can be achieved, and this would surely facilitate and ensure rapid sustainable socio-economic development of our great nation Nigeria.

\section{References}

Algera, G.F. (1989). PeaceStudies at the Cross Road. The Annals of the American Academy of Political and Social Sciences, 504,117127.

Azuh, K. (n.d). Inter-Tribal marriage: Panacea for Peace and Unity. Retrieved $15^{\text {th }}$ February 2020 from http://www.thepointernewsonline.com/?p=19669

Abdulrashed, H.A. (2013).TheRole of Religion In Building Culture Of Tolerance and Peace in Nigeria. A paper presented at the $9^{\text {th }}$ annual conference organized by the Association for Encouraging Qualitative Education in Nigeria, held 13 ${ }^{\text {th }}-17$ May 2013 at the Auditorium, Federal Polytechnic Auchi, Edo State.

Adegbulugbe, K.O.(2007). The Role of Intertribal Marriage in Fostering Peaceful Coexistence in Nigeria, A paper presented $3^{\text {rd }}$ annual conference of the Association for Encouraging 
Qualitative Education in Nigeria, held 8th-12 th June 2015 at Federal College of Education Agbor, Delta State.

Asuquo, E.E. (2013), Challenges of internal security in Nigeria. In Albert, 1.0 and Eselobor, W.A (Eds), Managing security in a Globalised World (pp 269-286). Ibadan: John Archer's publishers limited.

Chiegboka, A.B.C. (2012). The Catholic Church and the Marriage Bond. Awka: Fab AniehNig Ltd.

Francis, D.J. (2006), Peace and Conflict Studies; an African Overview of Basic Concepts. In S.G, Best (Ed), Introduction to Peace and Conflict Studies In West Africa. Ibadan: Spectrum Books Limited.

Global Policy Forum, (n.d). What is a Nation? Retrieved $4^{\text {th }}$ June 2020 https://www.globalpolicy.org/nations-a-states/what-is-anation.html.

Hornby, A.S. (2006), Oxford advance learner's dictionary. Oxford University Press.

Khurana, S. (n.d), National integration: complete information on meaning features and promotion of national integration in India. Retrieved on $13^{\text {th }}$ February 2020 from www.preservearticles.com/201012271786/nationalintegration.ht $\underline{\mathrm{ml}}$

Madu, .J.E. (2003), Paradox of "One" and the "Many" in Religion. Onitsha: Globe Communication.

Meliga, L.A. (2013), Inter Tribal Marriage: Fair or Snare? Retrieved $11^{\text {th }}$

February 2020 from http://www.qreatifdave.blogspot.in/2013/05/intertribal-marriagefairorsnar19.html?m1

Nikky, U.E. (2010), Concept of National Integration and Obstacles to National Integration. Retrieved $11^{\text {th }}$ February 2020 form www.indiastudychannel.com/resources/122094- Concept-ofNation-integration-And-Obstacles-To-National-integration.aspx 
Odukoya. B. (2003), How to Choose a Life Partner. Lagos: Grace Springs Publishers.

Onyeakazi, J. and Okoroafor E. C. (2018). National Integration in Nigeria: a Philosophical insight. Retrieved on $2^{\text {nd }}$ June 2020 https://www.researchgate.net/publication/331609153 NATIO NAL INTEGRATION IN NIGERIA_A_PHILOSOPHICAL_INSIGHT.

United States Conference of Catholic Bishops, (2014) Marriage. Retrieved $12^{\text {th }}$ February 2020 from http://www.usccb.org/issuesand-action/marriage-and-family/marriage/.

Weiner, M. (1967).Political Culture and Political Development. Princeton: Princeton University Press.

Christian Emeka Chukwu is a research assistant at Centre for Early Warning and Early Response System, Institute of Peace and Conflict Resolution, Nnamdi Azikiwe University, Awka, Nigeria. 